\title{
Phonological Short-Term Memory Impairment in Children with Down Syndrome
}

\author{
EMAN F. EL-WAKIL, M.Sc.**; RASHA M. SHOEIB, M.D.*; YOSSRA A.N. SALLAM, M.D.** and \\ MAHA H. BOSHNAQ, M.D.* \\ The Department of ENT, Phoniatrics Unit, Faculty of Medicine, Ain Shams* and Al-Azhar** Universities, Cairo, Egypt
}

\begin{abstract}
Background: Children with Down Syndrome commonly suffer from phonological and other language disorders which have been partly attributed to underlying deficit in phonological short term memory. Its evaluation was previously confined to non word repetition and/or forward digit span tasks.

Aim of Study: To assess phonological short term memory in children with Down Syndrome with mild degree of intellectual disability in comparison with non syndromic children with mild degree of intellectual disability to find out any possible correlation between Down Syndrome and phonological short term memory deficits through comprehensive evaluation.
\end{abstract}

Subjects and Methods: This case control study has been conducted on 40 children (20 Down Syndrome children with mild degree of intellectual disability, 20 non syndromic children with mild degree of intellectual disability with matched mental age). All of them underwent psychometric evaluation, audiological evaluation, language evaluation using Arabic version of Modified Preschool Language Scale-4th edition (PLS-4), and Arabic version of Phonological Short Term Memory Test (PSTM).

Results: Down Syndrome group scored significantly lower than non syndromic children with mild degree of intellectual disability in all items of phonological short term memory test; digit span, syllable repetition, non sense word repetition, dissimilar word set recall, similar word set recall, total score ( $p$-value $0.000,0.001,0.004,0.000,0.000,0.000$ respectively) and language test; expressive abilities was lower in Down syndrome children ( $p$-value 0.002$)$ but both groups were equal in their receptive abilities ( $p$-value 0.054 ).

Conclusion: Children with Down Syndrome scored below expected for phonological short term memory and their phonological store was extensively impaired.

Key Words: Down Syndrome - Intellectual disability - Phonological short term memory - Phonological store - Language disorders.

Correspondence to: Dr. Eman F. El-Wakil,

E-Mail: emanalwakee191@gmail.com

\section{Introduction}

PHONOLOGICAL Short Term Memory (PSTM) is the part of working memory responsible for transient holding of auditory information before their manipulation [1]. Its main function is vocabulary acquisition through maintaining the correct order of sounds in each word [2]. It has two components; the phonological store and the articulatory or subvocal rehearsal. The phonological store loads age appropriate number of auditory verbal segments for about 3 seconds before releasing them as spoken units or transferring them to subvocal rehearsal. The subvocal rehearsal typically echoes the received information in a process similar to that of inner speech [3].

Down Syndrome (DS) is a genetic-related disorder due to triplication of Chromosome 21. There are approximately 6 million people with DS around the world, most of them without a completely independent life [4]. The triplication of chromosome 21 in children with DS is responsible for their phenotypic variability and Intellectual Disability (ID) [5].

Evidence has suggested that DS is associated with PSTM deficits, especially in storage and not in the rehearsal function [6]. Deficits in PSTM in children with DS have been previously attributed to ID or accompanying mild to moderate Conductive Hearing Loss (CHL), which is common among DS [7]. However, in the absence of the above mentioned co-morbidities DS children continue to show impaired PSTM [8].

PSTM has been traditionally assessed using Non Word Repetition (NWR) task or, to a lesser extent, forward digit span task [9]. 


\section{Aim of the work:}

To assess PSTM in children with DS with mild degree of ID in comparison with non syndromic children with mild degree of ID to find out any possible correlation between DS and PSTM deficits through comprehensive evaluation.

\section{Subjects and Methods}

This observational case control study was carried out during the period from January 2020 to September 2020 in the outpatient clinic of the Unit of Phoniatrics, ENT Department of Ain Shams University Hospitals (El-Demerdash Hospital and Ain Shams University Specialized Hospital) and Al-Azhar University Hospital (Al-Zahraa Hospital). The study was approved by the Ethics Board of Ain Shams University and an informed written consent was taken from each participant in the study. It was conducted on two groups of children, in the age range of 6-12 years old:

- Group (I) (study group): 20 children with DS with mild degree of ID.

Exclusion criteria for the study group: DS with accompanying Autism Spectrum Disorder (ASD), Attention Deficit Hyperactivity Disorder (ADHD), hearing impairment, moderate and severe ID.

- Group (II) (control group): 20 non syndromic children with mild degree of ID.

Children of the two groups have been subjected to the protocol of language evaluation [10], psychometric evaluation by Arabic version of StanfordBinet Intelligence Scale $5^{\text {th }}$ edition [11], Arabic version of modified PLS-4 [12] to measure receptive language age, expressive language age and total language age, Arabic version of PSTM test [7] to measure digit span, syllable repetition, non sense word repetition, dissimilar word set recall and similar word set recall, and audiological evaluation (pure tone audiometry and tympanometry).

Children with history of recurrent otitis media during early childhood, or with sensorineural hearing loss were excluded from the study.

\section{Data management and analysis:}

The Statistical Package for Social Sciences (SPSS) version20 has been used for statistical analysis.

\section{Results}

Descriptive statistics of chronological age, mental age, Intelligence Quotient (IQ) and sex of both groups are shown in (Table 1).
In group (I); the chronological age range (years) was 6 years- 11 years 8 months with Mean \pm SD $(8.7 \pm 1.7)$, the mental age range (years) was 3 years6 years 6 months with mean \pm SD $(4.8 \pm 1.1)$ and the IQ range was (50-66) with mean \pm SD (54.9 \pm 4.3). While in group (II); the chronological age range (years) was 6 years-11 years 9 month with mean \pm SD $(7.9 \pm 1.8)$, the mental age range (years) was 3 years 3 months- 6 year 5 months with mean $\pm \mathrm{SD}(4.7 \pm 1.1)$ and the IQ range was (50-68) with mean \pm SD $(59.7 \pm 6.5)$. There were $14(70 \%)$ males and $6(30 \%)$ females in group (I), $12(60 \%)$ males and $8(40 \%)$ females in group (II). The results of audiological evaluation of both groups were normal.

The results of the language evaluation using the Modified (PLS-4), the Arabic version [12]: The receptive language age, expressive language age and total language age of both groups are shown in (Table 2).

In group (I); the receptive language age range (years) was 2 years 2 months-6 years 1 month with mean \pm SD (4.1 \pm 1.2$)$, the expressive language age range (years) was 1 year 7 months- 5 years 7 months with mean $\pm \mathrm{SD}(3.5 \pm 1.3)$ and the total language age range (years) was 2 years 1 month-5 years 6 months with mean \pm SD $(3.8 \pm 1.1)$. While in group (II); the receptive language age range (years) was 3 years 3 months- 6 years with mean \pm SD $(4.7 \pm 0.7)$, the expressive language age range (years) was 3 years 4 months -5 years 7 months with mean \pm SD $(4.5 \pm 0.6)$ and the total language age range (years) was 3 years 6 months -5 years 8 months with mean $\pm \operatorname{SD}(4.6 \pm 0.5)$.

Results of the PSTM test, the Arabic version [2] of both groups are shown in (Table 3).

In group (I); the digit span raw score range was $(0-2)$ with mean \pm SD $(0.9 \pm 0.6)$, the syllable repetition raw score range was (3-10) with mean \pm SD $(6.1 \pm 1.9)$, the non sense word repetition raw score range was (2-28) with mean \pm SD (12.9 \pm 7.9$)$, the dissimilar word set recall raw score range was (0-6) with mean \pm SD $(2.1 \pm 1.8)$, the similar word set recall raw score range was $(0-2)$ with mean \pm $\mathrm{SD}(0.7 \pm 0.7)$ and the total raw score range was $(6-$ 46) with mean \pm SD $(22.6 \pm 11.7)$. While in group (II); the digit span raw score range was (1-3) with mean \pm SD $(1.9 \pm 0.7)$, the syllable repetition raw score range was (4-12) with mean $\pm \mathrm{SD}(8.6 \pm 2.4)$, the non sense word repetition raw score range was (9-34) with mean \pm SD (20.6 \pm 7.9$)$, the dissimilar word set recall raw score range was (1-10) with mean \pm SD $(5.0 \pm 2.7)$, the similar word set recall raw score range was (0-6) with mean $\pm \mathrm{SD}(2.6 \pm$ 
1.9) and the total raw score range was (16-63) with mean \pm SD $(38.6 \pm 14.5)$.

Comparison between DS children with mild degree of ID and non syndromic children with mild degree of ID regarding the mental age is shown in (Table 4).

There were no statistically significant differences between the two groups regarding the mental age ( $p$-value 0.757$)$.

Comparison between DS children with mild degree of ID and non syndromic children with mild degree of ID regarding the language ages (receptive, expressive, and total language ages) by the Modified (PLS-4), the Arabic version [12] are shown in (Table 5).

There were statistically significant differences between the two groups regarding expressive language age and total language age ( $p$-value 0.002 , 0.010 ) respectively. While, there was no statistically significant differences between the two groups regarding receptive language age ( $p$-value 0.054$)$.

Comparison between DS children with mild degree of ID and non syndromic children with mild degree of ID regarding the scores of subtests of the PSTM test, the Arabic version [2] are shown in (Table 6).

There were statistically significant differences between the two groups regarding the scores of subtests of the PSTM test (digit span, syllable repetition, non sense word repetition, dissimilar word set recall, similar word set recall and total score) ( $p$-value 0.000, 0.001, 0.004, 0.000, 0.000, $0.000)$ respectively.

Table (1): The demographic data of group (I) and group (II).

\begin{tabular}{|c|c|c|c|c|}
\hline Variables & $\begin{array}{c}\text { Group (I) } \\
\text { Children with } \\
\text { DS with mild } \\
\text { degree of ID } \\
\quad(n=20)\end{array}$ & & \multicolumn{2}{|c|}{$\begin{array}{c}\text { Group (II) } \\
\text { Non syndromic } \\
\text { children with } \\
\text { mild degree of ID } \\
\quad(n=20)\end{array}$} \\
\hline $\begin{array}{l}\text { Chronological age (years) } \\
\text { Mean } \pm \text { SD } \\
\text { Range (min-max) }\end{array}$ & $\begin{array}{l}8.7 \pm 1.7 \\
(6.0-11.8)\end{array}$ & & $\begin{array}{l}7.9 \pm 1.8 \\
(6.0-11.9)\end{array}$ & \\
\hline $\begin{array}{l}\text { Mental age (years): } \\
\text { Mean } \pm \text { SD } \\
\text { Range (min-max) }\end{array}$ & $\begin{array}{l}4.8 \pm 1.1 \\
(3.0-6.6)\end{array}$ & & $\begin{array}{l}4.7 \pm 1.1 \\
(3.3-6.5)\end{array}$ & \\
\hline $\begin{array}{l}I Q: \\
\quad \text { Mean } \pm \mathrm{SD} \\
\quad \text { Range (min-max) }\end{array}$ & $\begin{array}{l}54.9 \pm 4.3 \\
(50-66)\end{array}$ & & $\begin{array}{l}59.7 \pm 6.5 \\
(50-68)\end{array}$ & \\
\hline Sex: & Number & $\%$ & Number & $\%$ \\
\hline $\begin{array}{l}\text { Males } \\
\text { Females }\end{array}$ & $\begin{array}{l}14 \\
6\end{array}$ & $\begin{array}{l}70 \\
30\end{array}$ & $\begin{array}{l}12 \\
8\end{array}$ & $\begin{array}{l}60 \\
40\end{array}$ \\
\hline
\end{tabular}

Table (2): The results of the language evaluation using the modified (PLS-4), the Arabic version.

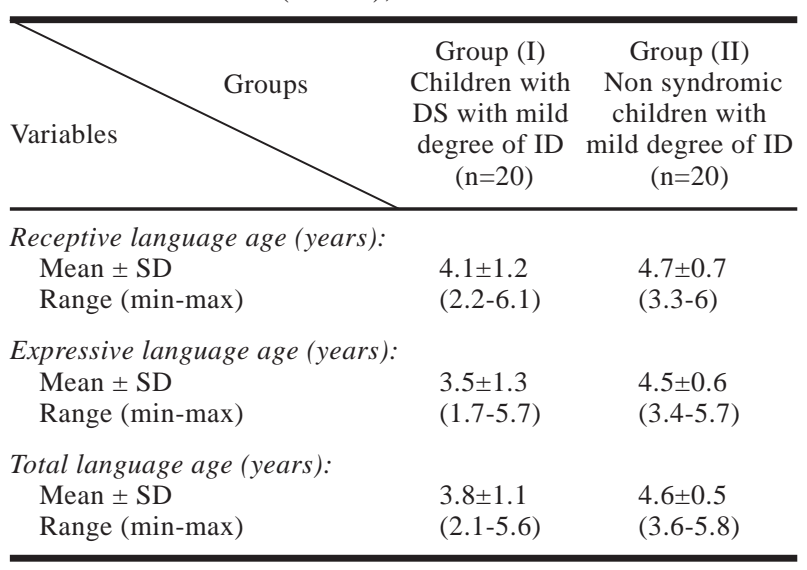

Table (3): The mean and standard deviation of the scores of subtests of the PSTM test, the Arabic version of the study groups.

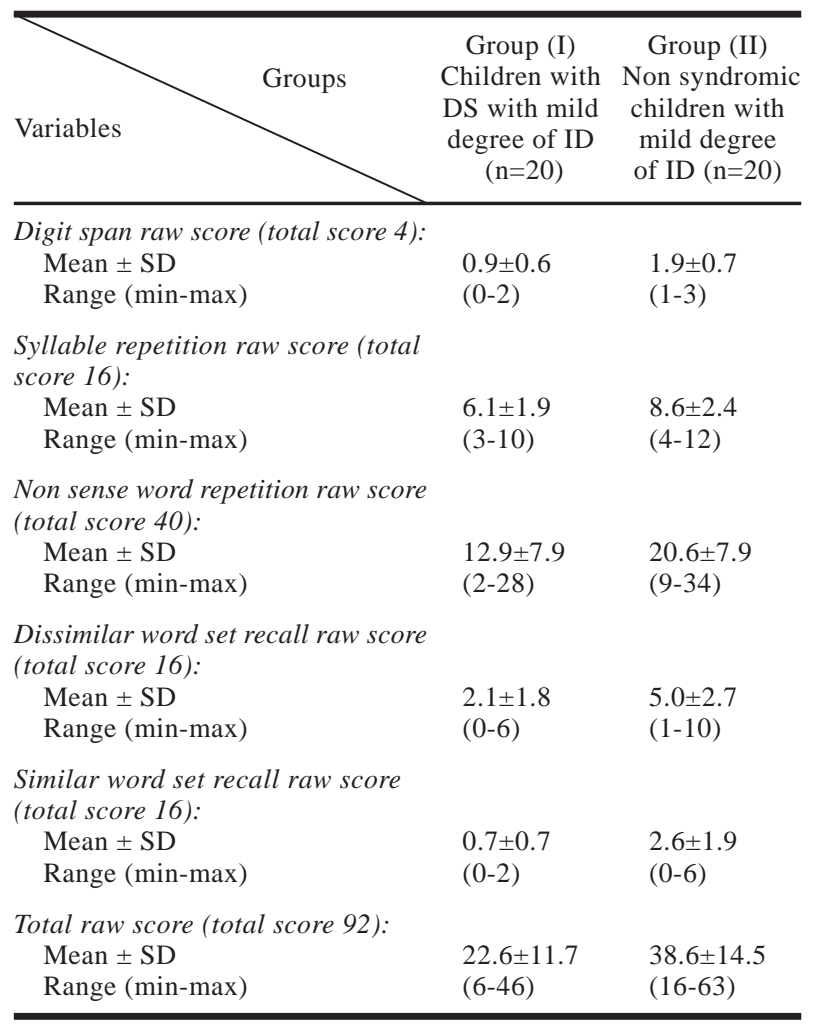

Table (4): Comparison between DS children with mild degree of ID and non syndromic children with mild degree of ID regarding the mental age.

\begin{tabular}{|c|c|c|c|c|c|}
\hline Groups & $\begin{array}{c}\text { Group (I) } \\
\text { Children with }\end{array}$ & $\begin{array}{c}\text { Group (II) } \\
\text { Non syndromic }\end{array}$ & & $t$-test & \\
\hline Variables & $\begin{array}{l}\text { DS with mild } \\
\text { degree of ID } \\
(n=20)\end{array}$ & $\begin{array}{l}\text { mild degree } \\
\text { of ID } \\
(n=20)\end{array}$ & $t$ & $\begin{array}{c}p- \\
\text { value }\end{array}$ & Sig. \\
\hline $\begin{array}{l}\text { Mental age (years): } \\
\text { Mean } \pm \text { SD } \\
\text { Range (min-max) }\end{array}$ & $\begin{array}{l}4.8 \pm 1.1 \\
(3.0-6.6)\end{array}$ & $\begin{array}{l}4.7 \pm 1.1 \\
(3.3-6.5)\end{array}$ & 0.31 & 0.757 & NS \\
\hline
\end{tabular}


Table (5): Comparison between both groups regarding the language ages (receptive, expressive, and total language ages) by the Modified (PLS-4), the Arabic version.

\begin{tabular}{|c|c|c|c|c|c|}
\hline Groups & $\begin{array}{c}\text { Group (I) } \\
\text { Children } \\
\text { with DS with }\end{array}$ & $\begin{array}{c}\text { Group (II) } \\
\text { Non } \\
\text { syndromic }\end{array}$ & & $t$-test & \\
\hline Variables & $\begin{array}{l}\text { mild degree } \\
\text { of ID } \\
(n=20)\end{array}$ & $\begin{array}{l}\text { children with } \\
\text { mild degree } \\
\text { of ID } \\
(n=20)\end{array}$ & $t$ & $\begin{array}{c}p- \\
\text { value }\end{array}$ & Sig \\
\hline
\end{tabular}

\begin{tabular}{|c|c|c|c|c|c|}
\hline \multicolumn{6}{|l|}{ Receptive language } \\
\hline \multicolumn{6}{|l|}{ age: } \\
\hline Mean \pm SD & $4.1 \pm 1.2$ & $4.7 \pm 0.7$ & 1.98 & 0.054 & NS \\
\hline Range (min-max) & $(2.2-6.1)$ & $(3.3-6)$ & & & \\
\hline \multicolumn{6}{|l|}{ Expressive language } \\
\hline \multicolumn{6}{|l|}{ age: } \\
\hline Mean \pm SD & $3.5 \pm 1.3$ & $4.5 \pm 0.6$ & 3.25 & $0.002 *$ & $\mathrm{~S}$ \\
\hline Range (min-max) & $(1.7-5.7)$ & $(3.4-5.7)$ & & & \\
\hline \multicolumn{6}{|l|}{ Total language age: } \\
\hline Mean \pm SD & $3.8 \pm 1.1$ & $4.6 \pm 0.5$ & 2.73 & $0.010^{*}$ & $\mathrm{~S}$ \\
\hline Range (min-max) & $(2.1-5.6)$ & $(3.6-5.8)$ & & & \\
\hline
\end{tabular}

$* p$-value is significant $<0.05$.

Table (6): Comparison between both regarding the scores of subtests of the PSTM test, the Arabic version.

\begin{tabular}{|c|c|c|c|c|c|}
\hline Groups & $\begin{array}{l}\text { Group (I) } \\
\text { Children } \\
\text { with }\end{array}$ & $\begin{array}{c}\text { Group (II) } \\
\text { Non } \\
\text { syndromic }\end{array}$ & & $t$-test & \\
\hline Variables & $\begin{array}{l}\text { DS with } \\
\text { mild degree } \\
\text { of ID } \\
(n=20)\end{array}$ & $\begin{array}{l}\text { children with } \\
\text { mild degree } \\
\text { of ID } \\
(n=20)\end{array}$ & $t$ & $\begin{array}{c}p- \\
\text { value }\end{array}$ & Sig. \\
\hline $\begin{array}{l}\text { Digit span raw score } \\
\text { (total score } 4) \text { : } \\
\text { Mean } \pm \mathrm{SD} \\
\text { Range (min-max) }\end{array}$ & $\begin{array}{l}0.9 \pm 0.6 \\
(0-2)\end{array}$ & $\begin{array}{l}1.9 \pm 0.7 \\
(1-3)\end{array}$ & 5.06 & $\begin{array}{l}p= \\
0.000 *\end{array}$ & $\mathrm{~S}$ \\
\hline $\begin{array}{l}\text { Syllable repetition } \\
\text { raw score (total } \\
\text { score } 16) \text { : } \\
\quad \text { Mean } \pm \text { SD } \\
\text { Range (min-max) }\end{array}$ & $\begin{array}{l}6.1 \pm 1.9 \\
(3-10)\end{array}$ & $\begin{array}{l}8.6 \pm 2.4 \\
(4-12)\end{array}$ & 3.62 & $\begin{array}{l}p= \\
0.001 *\end{array}$ & $\mathrm{~S}$ \\
\hline $\begin{array}{l}\text { Non sense word } \\
\text { repetition raw score } \\
\text { (total score } 40) \text { : } \\
\quad \text { Mean } \pm \mathrm{SD} \\
\text { Range (min-max) }\end{array}$ & $\begin{array}{l}12.9 \pm 7.9 \\
(2-28)\end{array}$ & $\begin{array}{l}20.6 \pm 7.9 \\
(9-34)\end{array}$ & 3.06 & $\begin{array}{l}p= \\
0.004 *\end{array}$ & $\mathrm{~S}$ \\
\hline $\begin{array}{l}\text { Dissimilar word set } \\
\text { recall raw score } \\
\text { (total score } 16) \text { : } \\
\quad \text { Mean } \pm \mathrm{SD} \\
\quad \text { Range (min-max) }\end{array}$ & $\begin{array}{l}2.1 \pm 1.8 \\
(0-6)\end{array}$ & $\begin{array}{l}5.0 \pm 2.7 \\
(1-10)\end{array}$ & 4.07 & $\begin{array}{l}p= \\
0.000 *\end{array}$ & $\mathrm{~S}$ \\
\hline $\begin{array}{l}\text { Similar word set } \\
\text { recall raw score } \\
\text { (total score } 16) \text { : } \\
\quad \text { Mean } \pm \mathrm{SD} \\
\text { Range (min-max) }\end{array}$ & $\begin{array}{l}0.7 \pm 0.7 \\
(0-2)\end{array}$ & $\begin{array}{l}2.6 \pm 1.9 \\
(0-6)\end{array}$ & 4.20 & $\begin{array}{l}p= \\
0.000 *\end{array}$ & $\mathrm{~S}$ \\
\hline $\begin{array}{l}\text { Total raw score (total } \\
\text { score } 92 \text { ): } \\
\text { Mean } \pm \mathrm{SD} \\
\text { Range (min-max) }\end{array}$ & $\begin{array}{l}22.6 \pm 11.7 \\
(6-46)\end{array}$ & $\begin{array}{l}38.6 \pm 14.5 \\
(16-63)\end{array}$ & 3.85 & $\begin{array}{l}p= \\
0.000 *\end{array}$ & $\mathrm{~S}$ \\
\hline
\end{tabular}

$* p$-value is significant $<0.05$.

\section{Discussion}

In the past few decades many studies have investigated PSTM in children with delayed language development and dyslexia [13,14]. However, limited research has been done on children with DS.

The current study assessed language and PSTM in DS children with mild degree of ID and compares their scores in subtest items against non syndromic children with mild degree of ID and matched mental age.

The modified PLS-4 Arabic version [12] and PSTM test Arabic version [2] are comprehensive valid diagnostic tools. Arabic PSTM test is characterized by its comprehensive evaluation of PSTM through variable parameters which include; digit span as a function of the phonological loop, syllable repetition as a convenient measure for children with articulation disorders, NWR as a neat measure of PSTM, similar and dissimilar word set recall to measure the influence of similarity on PSTM. Words of variable length have been used in the later items to investigate the effect of word length on PSTM [2].

Regarding language age, DS group scored significantly lower than non syndromic children with mild degree of ID group regarding expressive and total language ages but equal in receptive language age. Kumin [15] correlated the impairment in expressive language to the presence of extra copy of chromosome 21 and stated that this deficit is out of proportion to the mental age. Koizumi et al., [16] attributed non-significant difference between both groups in their receptive language age to the assumption that language development depend on the collaboration of many factors like the phonological long-term memory capacity and other cognitive processing functions including converting STM to LTM, memory retrieval, and semantic information processing, among others.

It has been assumed that optimal language acquisition needs adequate PSTM abilities. As regards receptive language, PSTM is important for understanding long sentence [17]. As for expressive language, PSTM is specifically important for the normal development of syntax (especially grammatical morphemes) and increasing the mean length of utterance [18].

Regarding PSTM, DS group scored significantly lower than non-syndromic children with mild degree of ID group regarding the scores of subtests of the PSTM test (digit span, syllable repetition, 
non sense word repetition, dissimilar word set recall, similar word set recall, total score). The likelihood of PSTM deficit among children with DS has been stated by Lee et al., [19]; Næss et al., [20]. But the nature of the deficit remained as a major challenge. Godfrey and Lee [6] stated that the problem lies within storage component of PSTM and explained their hypothesis on the basis that subvocal rehearsal develops at or after the age of 7 years with matching mental age. They added that the mental age of most of children with DS in all the studies has not reached 7 years. Most or even all these studies have used one task only either NWR task or forward digit span task for the assessment of PSTM as Penke and Wimmer [8]. The Arabic PSTM test distinguishes itself by covering all the parameters of PSTM. The significant deficit in the scores of the DS group indicates an underlying general impairment of all components of PSTM.

On the other hand, Mackenzie and Hulme [21] claimed that PSTM impairment is not specific to DS because they scored similar to ID children included in their study. However, the results of their study may be criticised because all of the children suffered from severe ID which severely hinders the development of any cognitive function. However, in the current study the gap between PSTM and intellectual disabilities was disproportionately higher in children with DS than in non syndromic children with mild degree of ID which indicates the presence of specific deficits in PSTM in the former group.

\section{Conclusion:}

Children with DS scored below expected for PSTM and their phonological store was extensively impaired.

\section{Recommendations:}

The higher susceptibility to PSTM impairment in DS children, as well as the importance of PSTM skills for further language development and academic careers, should be considered in their rehabilitative plans, so:

- Advocate the importance for early incorporation of PSTM therapy into their intervention programs to avoid the future delay of language skills.

\section{References}

1- DESCHAMPS I., COURSON M., DICK A S. and TREMBLAY P.: The phonological loop: Is speech special? Experimental Brain Research, 238: 2307-21, 2020.

2- EL NESHWEY H.M., BARAKA M.A., RIFAIE N.A., SABER A.S. and SARWAT S.A.: Construction of The Arabic Phonological Short Term Memory Test on Egyptian
Children. The Egyptian Journal of Hospital Medicine, 72 (7): 4866-73, 2018.

3- MARVEL C. and DESMOND J.: Functional topography of the cerebellum in verbal working memory. Neuropsychology Rev., 20: 271-9, 2010.

4- Global Down Syndrome Foundation: Facts and FAQ About Down Syndrome, 2019.

5- ARIMA-YOSHIDA F., RAVEAU M., SHIMOHATA A., AMANO K., FUKUSHIMA A., WATANAVE M., KOBAYASHI S., HATTORI S., USUI M., SAGO H., et al.: Impairment of spatial memory accuracy improved by Cbr1 copy number resumption and GABAB receptordependent enhancement of synaptic inhibition in Down syndrome model mice. Scientific Reports, 10: 14187, 2020.

6- GODFREY M. and LEE N R.: Memory profiles in Down syndrome across development: A review of memory abilities through the life span. Journal of Neurodevelopmental Disorders, 10 (1): 5, 2018.

7- DAVIES B.: Auditory disorders. In Stratford B., Gunn P. (Eds.), New approaches to Down syndrome, 100-21. Cassell, 1996.

8- PENKE M. and WIMMER E.: Verbal short-term memory and sentence comprehension in German children and adolescents with Down syndrome: Beware of the task. First language, 1-23, 2020.

9- ANDERSON J.D., WAGOVICH S.A. and BROWN B T.: Phonological and Semantic Contributions to Verbal ShortTerm Memory in Young Children with Developmental Stuttering. J. Speech Lang Hear Res., 62 (3): 644-67, 2019.

10- KOTBY M.N., KHAIRY A., BARAKA M., RIFAIE N., and EL SHOUBARY A.: Language testing of Arabic speaking children. Proceedings of the XXIII World Congress of International Association of Logopedics and Phoniatrics. Cairo, August 6-10, 1995.

11- HANOURA M.A.: Stanford Binet Intelligence test: Arabic version (5 $5^{\text {th }}$ edition). Anglo Press: Cairo, Egypt, 2002.

12- ABOU HASSIBA A., El SADY S., El SHOBARY A., GAMAL AAELDIN N., IBRAHIEM A. and OWEYS A.: Standardization, Translation and Modification of the Preschool Language Scale-4 [A doctoral dissertation], Faculty of Medicine, Ain Shams University, 2011.

13- WARING R., EADIE P., LIOW S R. and DODD B.: Do children with phonological delay have phonological shortterm and phonological working memory deficits? Child Language Teaching and Therapy, 33 (1): 33-46, 2017.

14- MAJERUS S. and COWAN N.: The Nature of Verbal Short-Term Impairment in Dyslexia: The Importance of Serial Order. Frontiers in Psychology, 7: 1522, 2016.

15- KUMIN L.: Speech intelligibility and childhood verbal apraxia in children with Down syndrome. Down Syndrome Research \& Practice, 10: 10-22, 2006.

16- KOIZUMI M., MAEDA M., SAITO Y. and KOJIMA M.: Correlations between Syntactic Development and Verbal Memory in the Spoken Language of Children with Autism Spectrum Disorders and Down Syndrome: Comparison with Typically Developing Children. Psychology, 11: 1091-107, 2020. 
17- FUKAMIZU M. and FUJITA I.: Relationship between Sentence Comprehension and Phonological Short-Term Memory Span in Child Language Development. Japanese Journal of Speech, Language, and Hearing Research, 11: 29-35, 2014.

18- BADDELEY A.D., GATHERCOLE S.E. and PAPAGNO C.: The Phonological Loop as a Language Learning Device. Psychological Review, 105: 158-73, 1998.

19- LEE N.R., MAIMAN M. and GODFREY M.: What can neuropsychology teach us about intellectual disability? searching for commonalities in the memory and executive function profiles associated with Down, Williams, and fragile X syndrome, 51: 1-40, 2016.

20- NÆSS K.B., HALAAS L.S., HULME C. and MELBYLERVÄG M.: Language and verbal short-term memory skills in children with Down syndrome: A meta-analytic review. Research in Developmental Disabilities, 32 (6): 2225-34, 2011

21- MACKENZIE S. and HULME C.: Memory span development in Down's syndrome severely subnormal and normal subjects. Cognitive Neuropsychology, 2: 303-19, 1987.

\section{ضعف الذاكرة الصوتية قصيرة المدى دئ

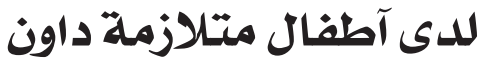

\footnotetext{
الهدف: يهدف البحث إلى تقييم الذاكرة الصوتية قصيرة المدى لدى آطفال متلازمة داون المصابين بالتآخر الفكرى البسيط مقارنة بالآطفال المصابين بالتآخر الفكرى البسيط لمعرفة العلاقة بين متلازمة داون وضعف الذاكرة الصوتية قصيرة المدىى.

الآسـاليب: آجريت هذه الدراسة على آربعين طفل (عشرين طفل من آطفال متلازمة داون المصابين بالتآخر الفكرى البسيط، عشرين طفل

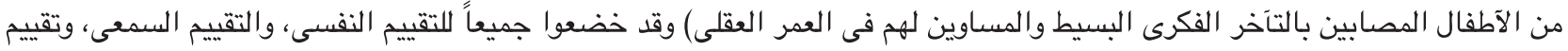

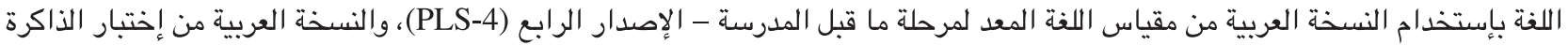
الصوتية قصيرة المدى (PSTM).

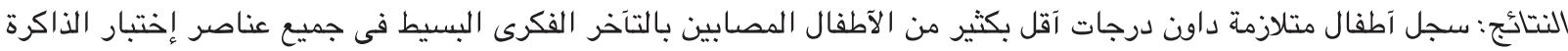

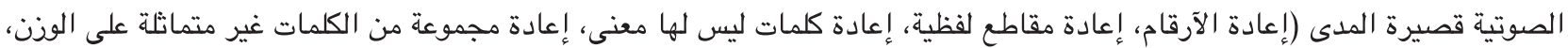

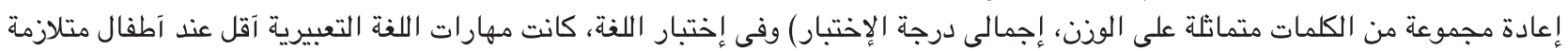
داون ولكن كلا المجموعتين كانتا متساويتين في مهارات اللغة الفئه الإستقبالية.

الخلاصة: سجل آطفال متلازمة داون درجات آقل من المتوقع فيما يتعلق بإختبار الذاكرة الصوتية قصيرة المدى كما وجد آن المخزن 